\title{
Katarzyna Ossowska
}

Uniwersytet Humanistyczno-Przyrodniczy Jana Kochanowskiego

w Kielcach

\section{Edukacyjny przekaz w periodykach dla młodzieży harcerskiej w latach 1911-1939 na przykładzie wybranych czasopism}

Od początku istnienia ruchu harcerskiego wydawane były rozmaite periodyki kierowane do grupy instruktorów, wychowawców harcerskich i harcerzy dorosłych oraz do dzieci i młodzieży harcerskiej. Były wśród nich miesięczniki, kwartalniki i czasopisma ukazujące się nieregularnie, były czasopisma docierające do harcerzy w całej Polsce oraz lokalne wydawane przez poszczególne środowiska. Marian Miszczuk w zestawieniu tytułów prasy harcerskiej z omawianego okresu przed wybuchem I wojny światowej po kres Drugiej Rzeczypospolitej, wymienia 247 tytułów ${ }^{1}$.

Najważniejszą pozycją wśród harcerskich periodyków dla młodzieży wydaje się miesięcznik „Harcerz” wydawany w latach 1917-1921 i 1925-1939 w Warszawie. Na jego popularność wpłynął fakt, że każdy zastęp zobowiązany był do jego prenumeraty ${ }^{2}$. Można zatem przypuszczać, że właśnie to czasopismo docierało do najszerszego grona młodzieży harcerskiej. Niewątpliwie wysoką pozycję należy też przypisać „Skautowi” wydawanemu we Lwowie. Ukazywał się on w latach 1911-1939, z przerwami w okresie I wojny światowej i wojny polsko-bolszewickiej ${ }^{3}$. Były to czasopisma o najszerszym zasięgu. Kolejna ważna pozycję to „Na Tropie”. To pismo publikowano z kolei w Katowicach w latach 1928-1939. W tych trzech czasopismach znaleźć można pokaźny zbiór artykułów edukacyjnych. Inne pisma kierowane do młodzieży harcerskiej to m. in. poznański „Czuj Duch”, „Harcerka” wydawana w Warszawie oraz z Krakowa „Płomienie” i „Skautka”.

Wśród zamieszczanych artykułów i informacji najliczniejszą grupę stanowiły te poświęcone idei harcerskiej, historii ruchu, informacje z życia drużyn, również emigracyjnych, a także krótkie opowiadania kierowane do młodzieży. Jednak wiele było też informacji związanych z rozmaitymi umiejętnościami

\footnotetext{
${ }^{1}$ M. Miszczuk, Spis tytułów prasy harcerskiej 1911-1939, Warszawa 1983, s. 4.

${ }^{2}$ Rozkaz K. M., „Harcmistrz”, wrzesień-październik 1917, s. 58.

${ }^{3}$ M. Miszczuk, Spis tytułów..., s. 23.
} 
i dziedzinami wiedzy, takimi jak geografia, przyroda, fizyka, historia, a także wskazówek dotyczących samodzielnej konstrukcji różnych urządzeń i opisów ćwiczeń gimnastycznych. Wiele spośród tych artykułów można powiązać $\mathrm{z}$ przedmiotami nauczanymi $\mathrm{w}$ szkołach okresu międzywojennego. W siedmioklasowej szkole powszechnej $\mathrm{z}$ lat dwudziestych nauczanymi przedmiotami były: religia, język polski, język obcy nowożytny, historia, geografia, nauka o przyrodzie, arytmetyka z geometrią, rysunki, roboty ręczne, śpiew, gimnastyka ${ }^{4}$.

T a b e la 1

Tematyka artykułów w czasopismach harcerskich ${ }^{5}$

\begin{tabular}{|l|c|c|c|}
\hline \multicolumn{1}{|c|}{ Tematyka artykułów } & „Harcerz” & „Na Tropie” & „Skaut” \\
\hline Nauka o przyrodzie & 25 & 44 & 15 \\
\hline Historia & 8 & 5 & 38 \\
\hline Geografia & 8 & 15 & 26 \\
\hline Technika, mechanika i fotografia & 10 & 12 & 14 \\
\hline Fizyka & 10 & 7 & 8 \\
\hline Gimnastyka i sport & 15 & 6 & 0 \\
\hline Wiedza o Polsce i świecie & 4 & 3 & 13 \\
\hline Roboty ręczne & 10 & 3 & 0 \\
\hline Pierwsza pomoc & 2 & 3 & 2 \\
\hline Język polski & 2 & 1 & 2 \\
\hline Przysposobienie obronne & 2 & 0 & 3 \\
\hline
\end{tabular}

Źr ó d ł o: oprac. własne.

W tabeli 1 i na wykresie 1 zamieszczone zostało zestawienie ilościowe artykułów, z uwzględnieniem tematyki w nich poruszanej. Najwięcej spośród nich związanych było z nauką o przyrodzie, życiem roślin i zwierząt. Takich artykułów szczególnie dużo ukazało się w „Na Tropie”. Dosyć duża grupa dotyczyła tematyki związanej z geografią, terenoznawstwem, geomorfologią oraz fizyka, ze szczególnym uwzględnieniem informacji o falach radiowych i radioodbiornikach. W „Skaucie” było dużo artykułów poświęconych historii i wiedzy o Polsce, natomiast w „Harcerzu” można znaleźć wiele informacji na temat przyrody, sportu i sprzętu sportowego, zwłaszcza żeglarstwa, oraz wskazówki dotyczące montażu prostych urządzeń mechanicznych. Są też mniej liczne teksty związane

\footnotetext{
${ }^{4}$ S. I. Możdżeń, Historia wychowania 1918-1945, Sandomierz 2006, s. 76.

${ }^{5}$ Liczby zawarte w tabeli są podane w przybliżeniu, niektóre artykuły trudno było bowiem sklasyfikować.
} 
z pracami ręcznymi, pierwszą pomoca, zasadami obowiązującymi w języku polskim oraz przysposobieniem obronnym.

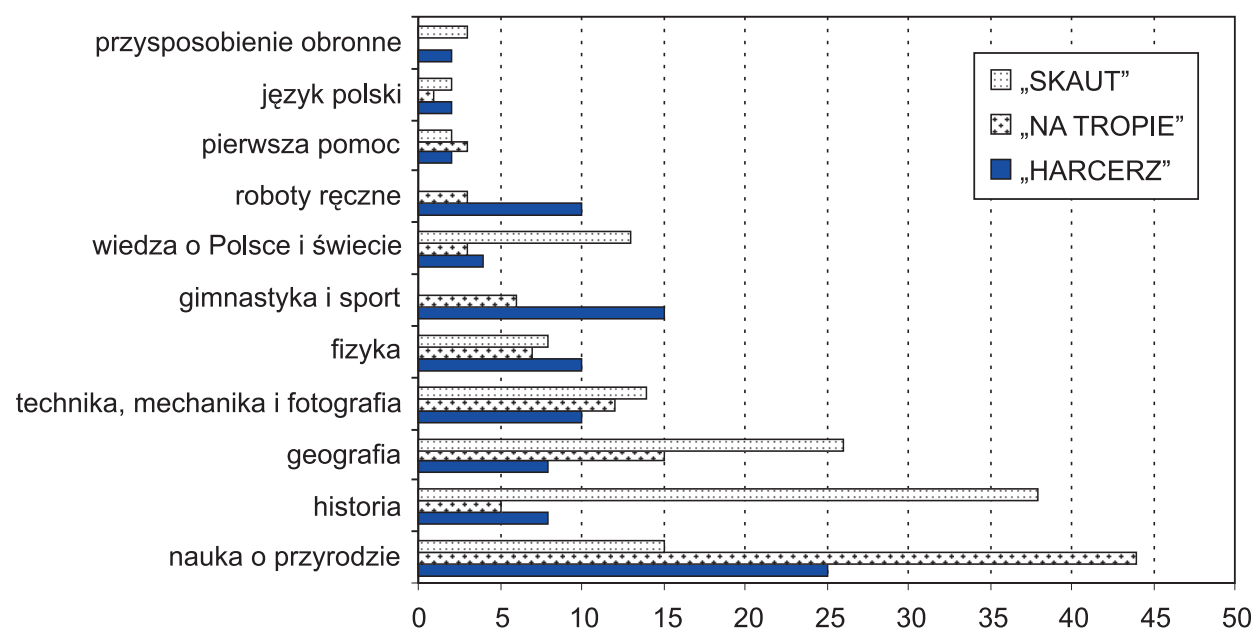

Wykres 1. Tematyka artykułów w czasopismach harcerskich

Część artykułów poruszających związane $\mathrm{z}$ tematem zagadnienia ukazywała się w cyklach w kilku bądź kilkunastu następujących po sobie numerach. Takie cykle to np. na łamach „Harcerza” „Piękno przyrody”, „Poznaj przyrodę”, pięć artykułów o zastosowaniu i historii radia, siedmioczęściowy cykl „Jak fotografować” oraz dwa najdłuższe cykle „Kurs żeglarski” - dwanaście artykułów i „Co skaut wiedzieć powinien?" - piętnaście artykułów. Ostatni z nich to zbiór krótkich tekstów poświęconych rozmaitej tematyce, od sposobów zabezpieczania płótna i utrzymania obuwia, po polskie przysłowia, wskazówki odnośnie do robienia przezroczy i przewidywania pogody. W „Skaucie” ukazała się seria „Co każdy z nas o Polsce wiedzieć powinien - osiem artykułów”, „Nauka o terenie” piętnaście i obszerny cykl poświęcony powstaniu styczniowemu. Na łamach „Na Tropie” również ukazało się kilka serii artykułów: „Podstawy radiotechniki dla początkujących”, „Wśród lodowców i fiordów Norwegii”, „Kalendarzyk leśnego człowieka”, cykl poświęcony kartografii oraz cykl ilustracyjny na temat drzew.

Wśród artykułów o tematyce przyrodniczej znaleźć można opisy gatunków zwierząt domowych (pies ${ }^{6}, \operatorname{kot}^{7}, \operatorname{kon}^{8}$ ) i nie tylko (kret, bóbr ${ }^{9}$, niedźwiedź ${ }^{10}$ ),

${ }^{6}$ Rodzina psów, „Skaut” [dalej - S] 1913, nr 8, s. 113-115; nr 9, s. 136-138; nr 10-11, s. $157-159$.

${ }^{7}$ Rodzina kotów, S, 1913, nr 7, s. 99-101.

${ }^{8}$ Koń, S, 1914, nr 20, s. 310-313; nr 22-24, s. 342-345.

${ }^{9}$ A. Kozłowska, Bobry na Polesiu, „Na Tropie” [dalej-NT] 1935, nr 7, s. 77.

${ }^{10}$ Niedźwiedzie, S, 1914, nr 12-13, s. 192. 
informacje o ochronie i sadzeniu lasu oraz bieżące wiadomości ze świata przyrody - jak zmienia się ona w zależności od pory roku. Można zaznajomić się ze sposobami na „Poznanie drzew i krzewów w porze zimowej”, w zimie bowiem trudniej rozróżnić drzewa i krzewy, jednak - jak się okazuje - nie jest to niemożliwe.

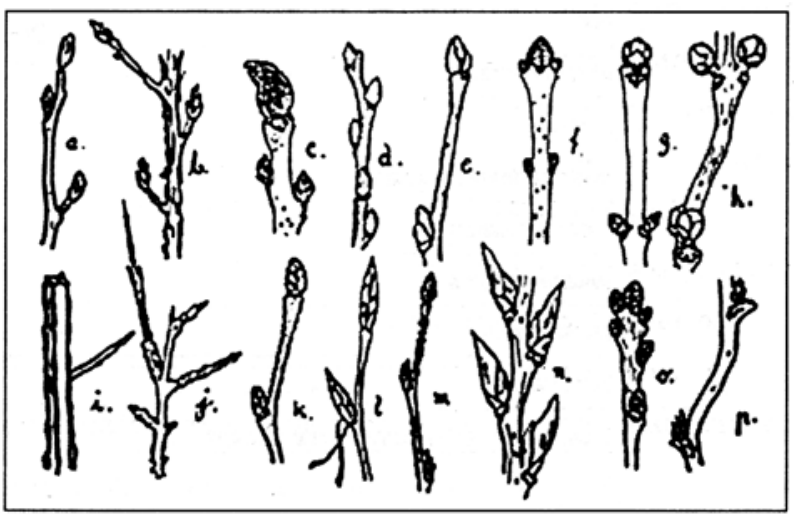

Ryc. 1. Pączki pospolitych drzew i krzewów (A. Kozłowska, Poznanie drzew i krzewów w porze zimowej, „Na Tropie” 1933, nr 1, s. 8)

Można je poznać po pączkach i łuskach otaczających listki, a także po ustawieniu na gałązkach: naprzeciwległym, naprzemianległym czy spiralnym ${ }^{11}$. Tropienie zwierząt opisane zostało w tekście Język śladów. Do najczęściej spotykanych należą ślady zająca. Co ciekawe, ślady tylnych łapek widziane są przed przednimi. Dzieje się tak dlatego, że zając poruszając się skokami „skręca się kompletnie i potem, rozpręża"12. Podobne są ślady królika, choć drobniejsze i w mniejszej odległości. Ślady lisa podobne są do śladów małego psa, można je jednak bez trudu rozróżnić po tym, gdzie są pozostawione. Lis, w przeciwieństwie do psa, unika ludzkich ścieżek, a na gruncie błotnym rozszerza łapę ${ }^{13}$. Ciekawe są dwa artykuły opisujące budowę atomową soli i węgla i jej wpływ na własności mechaniczne ciała. Regularna budowa wewnętrzna, uporządkowane ułożenie atomów, ma odzwierciedlenie w regularnym kształcie kryształu, np. soli kuchennej ${ }^{14}$. Węgiel występuje $\mathrm{w}$ przyrodzie $\mathrm{w}$ trzech postaciach: węgla, grafitu, diamentu. Nie różnią się one pod względem chemicznym, ale pod względem rozmieszczenia atomów. Atomy węgla w diamencie leżą na wierzchołkach czworościanu, z kolei w graficie układają się płaszczyznami sześcio-

\footnotetext{
${ }^{11}$ A. Kozłowska, Poznanie drzew i krzewów w porze zimowej, NT, 1933, nr 1, s. 8.

${ }^{12}$ J. Z., Język śladów, „Harcerz” [dalej - H] 1927, nr 11, s. 94.

${ }^{13}$ Tamże.

${ }^{14}$ Piękno przyrody. Budowa kryształów, H, 1925, nr 6, s. 12-13.
} 
kątnych siatek. Odległości między płaszczyznami są znaczne, przyczyniając się do łupliwości minerału. Czysty węgiel składa się z drobnych kryształków grafitu ${ }^{15}$.

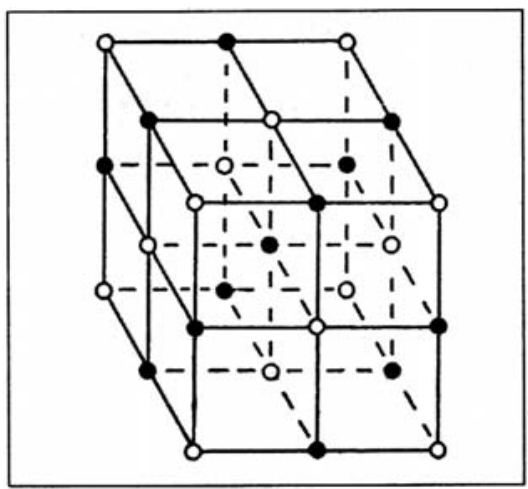

Ryc. 2. Budowa kryształów (Piękno przyrody. Budowa kryształów, „Harcerz” 1925, nr 6, s. 12)

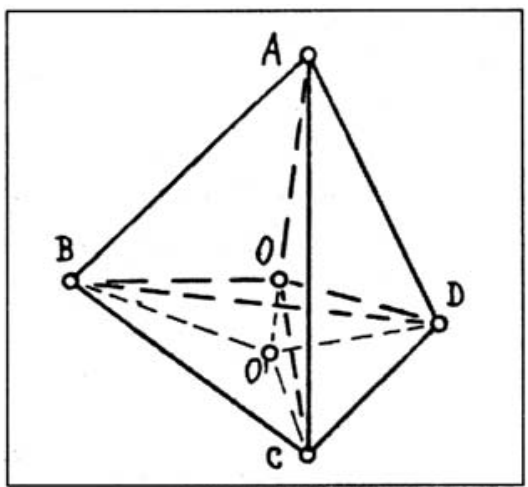

Ryc. 3. Budowa diamentu (Piękno przyrody. Wegiel, „Harcerz” 1925, nr 8, s. 17)

Do grupy publikacji o tematyce związanej z geografią można zaliczyć teksty dotyczące geologii, historii Ziemi, terenoznawstwa, kartografii. Spotkać można także elementy krajoznawcze, jak np. szkic o Dunaju ${ }^{16}$, Górach Świętokrzyskich $^{17}$, o Norwegii ${ }^{18}$. Autor artykułu Skąd się wzięty Tatry? przedstawia proces powstania najwyższych polskich gór. Tatry są górami fałdowymi orogenezy alpejskiej. Materiał, z którego są zbudowane, stanowią skały krystali-

${ }^{15}$ Piękno przyrody. Weqiel, H, 1925, nr 8, s. 17-18.

${ }^{16}$ S. Szymborski, Szlakiem Dunaju, NT, 1932, nr 6, s. 9.

${ }^{17}$ A. Kozłowska, Góry Świętokrzyskie, NT, 1932, nr 10, s. 5.

${ }^{18}$ Z. Wołowska, Wśród lodowców i fiordów Norwegii, NT, 1929, nr 5-6, s. 3-4; nr 7-8, s. $7-8 ;$ nr 9 , s. 8 . 


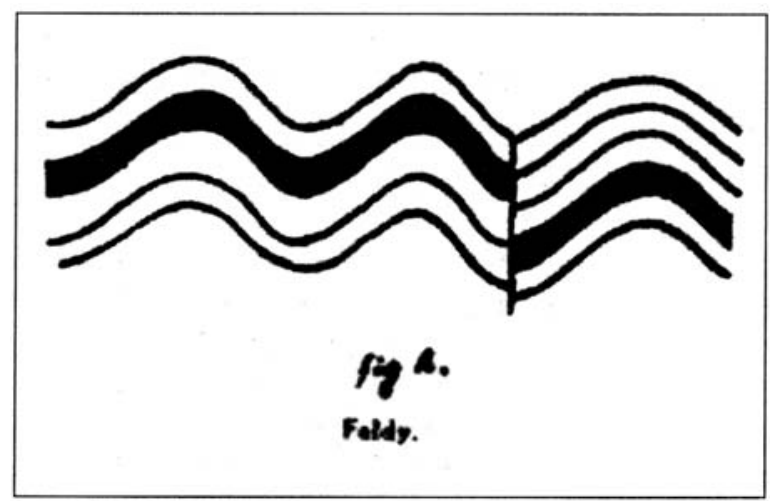

Ryc. 4. Fałdowanie górotwórcze (T. B., Skąd się wzięty Tatry?, „Harcerz” 1921, nr 6-7, s. 44)

czne, wapienie, dolomity. Przedstawione zostało również polodowcowe pochodzenie dolin, stawów i ostrych grani tatrzańskich oraz proces zanikania stawów przez wkraczanie stożków piargowych ${ }^{19}$. Orientowanie się $\mathrm{w}$ terenie zostało opisane w jednym z artykułów z cyklu „Nauka o terenie”20. Przedstawione zostało $\mathrm{w}$ nim $\mathrm{m}$. in. orientowanie mapy przez ustawienie jej górną krawędzią ku północy, wyznaczanie stron świata za pomocą kompasu, za pomocą słońca i zegarka oraz Gwiazdy Polarnej. Z treści wynika iż również księżyc może być pomocny: np. o północy księżyc znajduje się w I kwadrze na

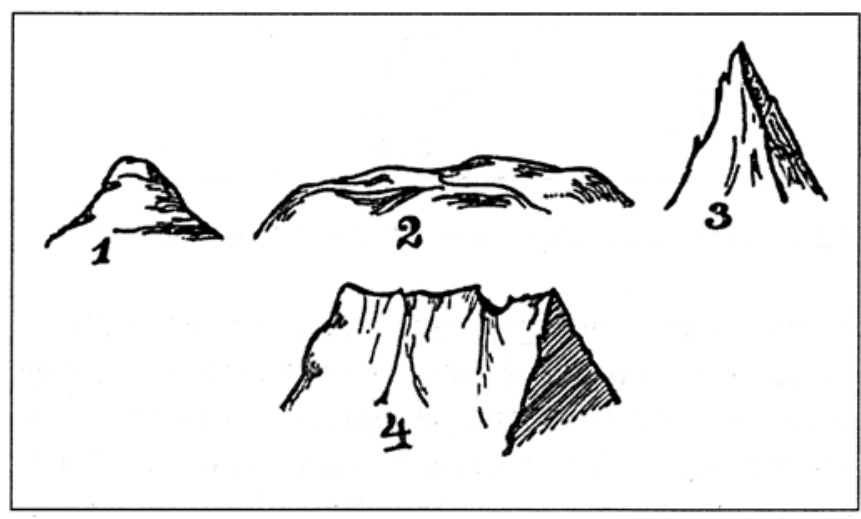

Ryc. 5. (X. Vocavelli, Nauka o terenie, „Skaut” 1912, nr 9, s. 10)

${ }^{19}$ T. B., Skad się wzięty Tatry?, H, 1921, nr 6-7, s. 43-46; H, 1921, nr 8-9, s. 59-61.

${ }^{20}$ Cykl artykułów X. Vocavelli, Nauka o terenie, S, 1912, nr 9, s. 7-10; nr 10, s. 7-10; nr 11, s. 7-9; nr 14, s. 8-9; nr 15, s. 7-8; nr 16, s. 5-7; nr 20-22, s. 4-8; nr 2 (24), s. 25-27; nr 3 (25), s. 42-44; nr 5 (27), s. 71-74; nr 6 (28), s. 90-92; S, 1913, nr 8 (30), s. 118-120. 
wschodzie, w pełni na południu, w ostatniej kwadrze na zachodzie. Wśród innych sposobów wyznaczania stron świata w terenie wymienione zostały: mech porastający północną stronę kamieni, samotnie rosnących drzew, lepiej rozwinięte gałęzie drzew od strony południowej, lokalizowanie prezbiteriów starszych kościołów ku wschodowi ${ }^{21}$. Kolejny artykuł z tego samego cyklu dotyczy ziemi: rodzaju gleb, ukształtowania terenu. Opisuje występujący układ pasów w budowie wielkich gór, kształty szczytów (1 - kopiasty, 2 - płaski, 3 - ostrosłupowy, 4 - dwuspadkowy) oraz rodzaje stoków (a - równe, b - wklęsłe, c wypukłe, $\mathrm{d}$ - faliste, e - tarasowate). Ukazany w nim został również wpływ poszczególnych czynników na warunki marszu ${ }^{22}$. Powstawanie źródeł omówione zostało w artykule $O$ źródłach. Woda gruntowa pozostaje w ciagłym ruchu w kierunku nachylenia płyty nieprzepuszczalnej. W miejscu, w którym warstwa nieprzepuszczalna wychodzi na powierzchnię ziemi, powstają źródła warstwowe. Źródła szczelinowe powstają przez krążenie wody szczelinami, wśród nieprzepuszczalnych skal. Występują one zwykle w górach.

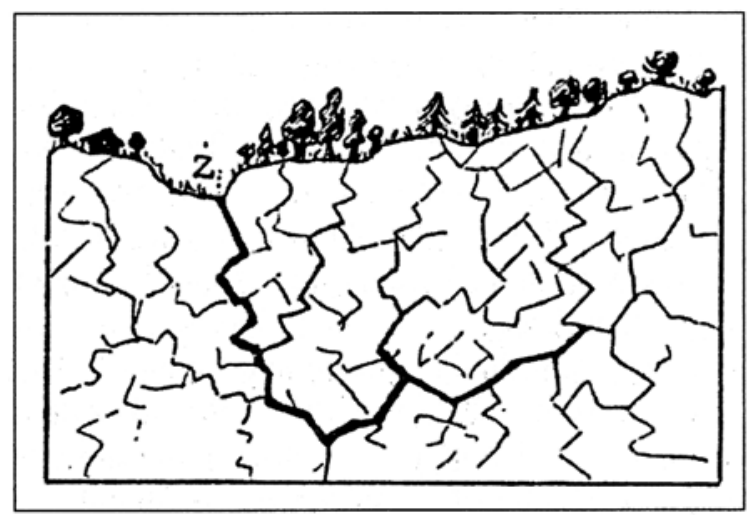

Ryc. 6. Źródło szczelinowe (O źródłach, „Skaut” 1913, nr 8, s. 120)

Obfitość i liczba źródeł zależy od przepuszczalności gruntu, nachylenia stoków, klimatu ${ }^{23}$. Artykuł Czy będzie pogoda? poświęcony jest umiejętności przewidywania pogody. Przytoczone zostały zjawiska przyrody, które mogą być uznane za zwiastuny mającej wystąpić aury. Tekst został podzielony na pięć części, które dotyczą kolejno cech długotrwałej słoty, pogody dżdżystej, burzy lub ulewy, polepszającego się stanu pogody i pogody stałej. Zjawiska przyrody, które zostały omówione, to $\mathrm{m}$. in. kierunek wiatru, przejrzystość powietrza, przede wszystkim zaś rodzaje chmur. Czytelnik mógł się dowiedzieć, że można się

\footnotetext{
${ }^{21}$ X. Vocavelli, Nauka o terenie. Orientowanie się $w$ terenie, S, 1912, nr 5, s. 71.

${ }^{22}$ X. Vocavelli, Nauka o terenie, S, 1912, nr 9, s. 7-10.

${ }^{23}$ O źródtach, S, 1913, nr 8, s. 119-121.
} 
spodziewać polepszenia pogody, gdy niewielkie chmury kłębiaste ciągną w tym samym kierunku, co i wiatr, lub gdy na niebie występuje tylko jedna warstwa chmur [...]. Dobrymi objawami są: wieczorna rosa i mgła, która się tworzy wieczorem lub w nocy w miejscach niżej położonych, a następnie znika przy wschodzie słońca ${ }^{24}$.

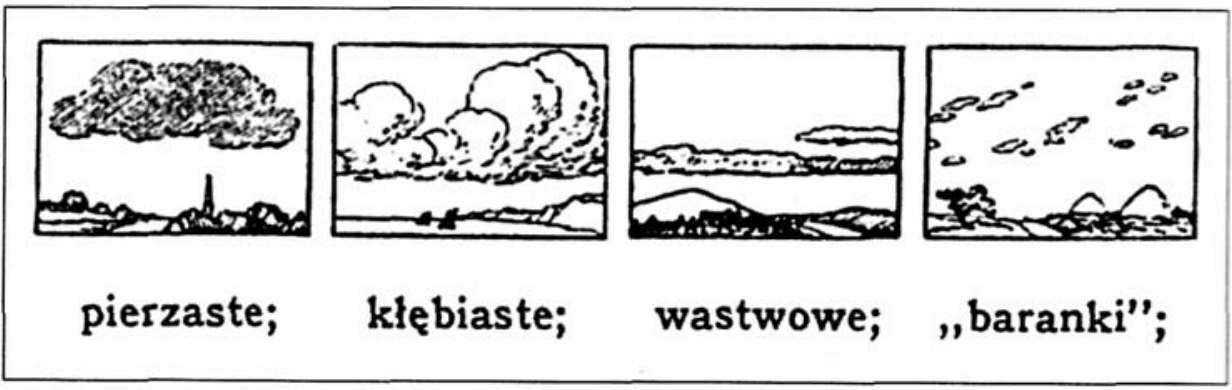

Ryc. 7. Rodzaje chmur (Czy będzie pogoda, „Harcerz”, marzec 1917 r., nr 1, s. 21)

Najwięcej artykułów związanych z historią, zwłaszcza historią Polski, znaleźć można w piśmie „Skaut”. Są to artykuły poświęcone postaciom związanym z dziejami narodu, a także ważnym wydarzeniom, obchodzonym rocznicom. Wśród opisywanych postaci należy wymienić Tadeusza Kościuszkę ${ }^{25}$, Jana Zamoyskiego $^{26}$, księcia Józefa Poniatowskiego ${ }^{27}$, Jana Henryka Dąbrowskiego ${ }^{28}$ czy Henryka Sienkiewicza ${ }^{29}$. Rocznice, które uczczone zostały na łamach tego pisma, to np. rocznica powstania kościuszkowskiego ${ }^{30}$, dziewięćsetna rocznica koronacji Bolesława Chrobrego ${ }^{31}$, rocznica bitwy pod Grunwaldem $^{32}$, pod Racławicami $^{33}$, rocznica uchwalenia Konstytucji 3 maja $^{34}$. Wiele uwagi poświęcono powstaniu styczniowemu. W latach 1912-1913 ukazał się cykl artykułów poświęconych Romualdowi Trauguttowi ${ }^{35}$ oraz powstaniu styczniowemu na Ukrainie $^{36}$, obozom powstańczym ${ }^{37}$, odezwom Komitetu Centralnego ${ }^{38}$ itp.

${ }^{24}$ Czy będzie pogoda, H, nr 1, marzec 1917, s. 21-22.

${ }^{25}$ Tadeusz Kościuszko, S, 1917, nr 18, s. 137-139.

${ }^{26}$ K. Tyszkowski, Młodość hetmańska [Ustęp z Żywotu Jana Zamoyskiego], S, 1925, nr 11-12, s. 129-131.

${ }^{27}$ Ksiażę Józef Poniatowski, S, 1913, nr 6, s. 81-83.

${ }^{28}$ J. Kohlerówna, Jan Henryk Dąbrowski. W stulecie zgonu, S, 1918, nr 11, s. 78-80.

${ }^{29}$ M. Kurysiówna, Henryk Sienkiewicz (W rocznicę śmierci), S, 1917, nr 20, s. 161-163.

${ }^{30}$ W rocznicę kościuszkowska, S, 1911, nr 2, s. 1-2.

${ }^{31}$ W 900 rocznice koronacji Chrobrego, S, 1925, nr 5, s. 66.

${ }^{32}$ Rocznica Grunwaldu, S, 1925, nr 6-7, s. 82.

${ }^{33}$ W racławicka rocznice, $\mathrm{S}, 1918, \mathrm{nr} 1-2$, s. 53.

${ }^{34}$ W rocznice Konstytucji 3 maja, S, 1918, nr 9, s. 61-62.

${ }^{35}$ Romuald Traugutt, S, 1912, nr 7, s. 6-7; nr 8, s. 5-8; nr 9, s. 4-7.

${ }^{36}$ Rok 1863. Solowjówka, ustęp z powstania na Ukrainie, S, 1913, nr 9, s. 135-137.

${ }^{37}$ Rok 1863. Obozy powstańcze, S, 1913, nr 10, s. 148-150.

${ }^{38}$ Rok 1863. Odezwy Komitetu Centralnego, S, 1913, nr 11, s. 162-164. 
W sumie było to kilkanaście artykułów. Ciekawy jest artykuł poświęcony bóstwom słowiańskim. Wymienieni i krótko opisani zostali najważniejsi bogowie ogólnosłowiańscy i pomorscy. (Bóstwa ogólnosłowiańskie: Swarog - bóg nieba, Swarożyc - bóg ognia, Daćbog - władca słońca i dawca bogactw, Perun - bóg gromów, Weles - władca świata podziemnego i duchów zmarłych, Siem i Rgieł - bóstwa gospodarcze, domowe, Pereplut - bóg przypadku i szczęścia. Bóstwa

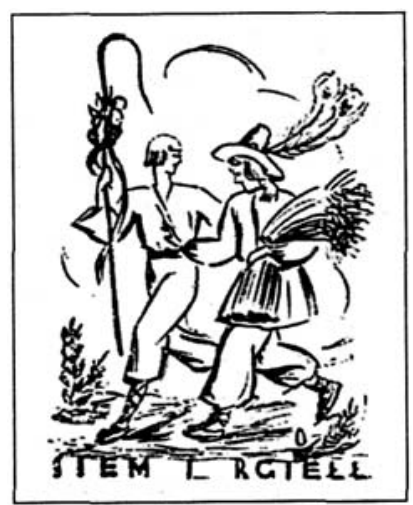

Ryc. 8. Siem i Rgieł (Bóstwa stowiańskie, „Skaut” 1929, nr 6, s.112)

pomorskie:Swantewit - bóg wojny i urodzaju, Jarowit - opiekun roślinności, Triglaw - miał trzy głowy na znak władzy nad ziemia, powietrzem i woda, Żywja - bóstwo życia, ładu i porządku). Artykuł został napisany na podstawie wykładów pracownika naukowego Uniwersytetu Jana Kazimierza, dr. Adama Fischera, wybitnego badacza kultury Słowian ${ }^{39}$. Również w pismach „Harcerz” $\mathrm{i}$ „Na Tropie” tematyka historyczna była podejmowana, jednak nie tak szeroko. Przywołać można artykuły poświęcone Bartoszowi Głowackiemu ${ }^{40}$, Tadeuszowi Kościuszce $^{41}$, koronacji Bolesława Chrobrego ${ }^{42}$, a także związane $\mathrm{z}$ historią regionalną - np. Wielkopolski ${ }^{43}$.

Często spotkać można artykuły zajmujące się techniką, mechaniką, fotografią, opisujące wykonanie prostych urządzeń. Krótki artykuł $O$ robieniu przezroczy ukazuje tani i szybki sposób samodzielnego ich przygotowania. Zdaniem autora może on być użyteczny szczególnie na prowincji, gdzie nie zawsze jest możliwość przygotowania fotografii. Istotą tej metody jest ręczne przekalkowywanie zdjęcia lub ilustracji na przezroczystym arkuszu żelatynowym (służącym do kopiowania, dostępnym w składzie przyborów rysunko-

${ }^{39}$ Bóstwa stowiańskie, S, 1929, $\mathrm{nr}$ 6, s. 110-114.

${ }^{40}$ C. Weckerówna, Bartosz Glowacki, H, 1926, nr 12-13, s. 146-147.

${ }^{41}$ H. Mościcki, Tadeusz Kościuszko, H, 1925, nr 6, s. 3-6.

${ }^{42}$ M. Cz. Przewóska, 900-lecie koronacji Chrobrego, H, 1925, nr 18, s. 3-5.

${ }^{43}$ Empe, Wielkopolska kolebka Państwa Polskiego, NT, 1929, nr 1-2, s. 2-3; tenże, Najdawniejsze dzieje Poznania, NT, 1929, nr 5-6, s. 1-2. 
wych). Gotowy rysunek, odpowiednio przycięty, winno się umieścić między szkiełkami chroniącymi przeźrocze ${ }^{44}$. „Kilka uwag o fotografii” to cykl poświęcony fotografowaniu od przygotowania aparatu i negatywu po robienie zdjęć. Przykładowo wykonywanie zdjęć „pod słońce” może spowodować prześwietlenie kliszy, a w efekcie przymglone bądź poszarzałe zdjęcia. Za pomocą przesłony można regulować czas naświetlania, a także uzyskać wyraźniejszy obraz. Długość czasu naświetlania zależy od czułości kliszy, wielkości otworu obiektywu, regulowanego przysłoną, przede wszystkim od natężenia światła $^{45}$. Znaleźć można było także wskazówki dotyczące montażu prostych urządzeń, np. instalacji dzwonkowej w domu. Wyliczone zostały potrzebne do tego materiały (dzwonek elektryczny, bateryjka kieszonkowa, kilkadziesiąt metrów drutu, gwoździe w kształcie litery U długości ok. 15 mm, kilkanaście śrubek i $1 \mathrm{~m}$ taśmy izolacyjnej), a następnie opisane zostały kolejne kroki montażu, poczynając od wyznaczenia drogi, którą będzie szedł drut, po owinięcie łączeń drutu taśmą izolacyjną ${ }^{46}$.

Dosyć liczne są publikacje związane z fizyką, szczególnie z elektrycznością i radiem ${ }^{47}$, jego zastosowaniem, historią ${ }^{48} \mathrm{i}$ zjawiskiem fal radiowych $\mathrm{w}$ ogóle ${ }^{49}$. W artykule Radio i jego zastosowanie omówiony został schemat i sposób wykonania jednolampowego aparatu radiowego. Do opisu dołączono prosty

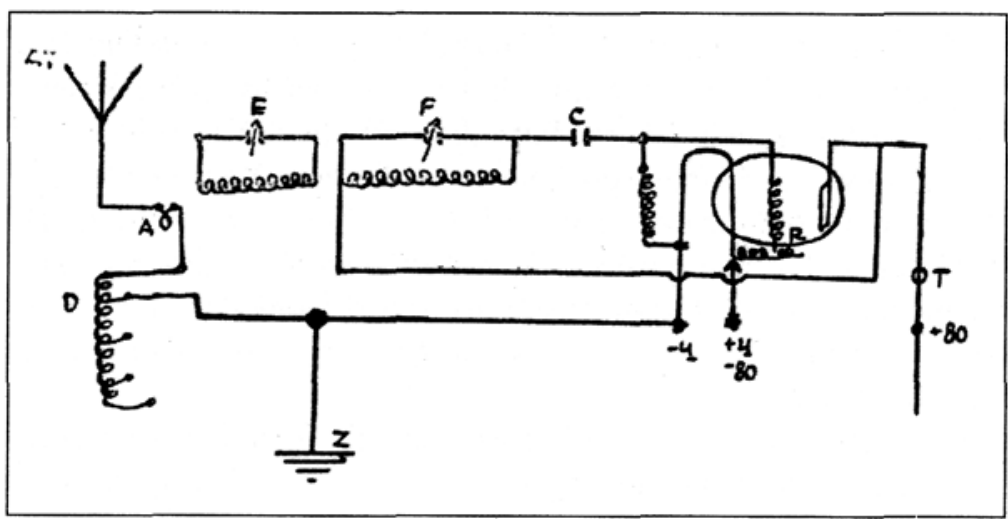

Ryc. 9. Detektorowy aparat radiowy (L. M., Radio i jego zastosowanie, „Harcerz” 1925, nr 8, s. 21)

${ }^{44}$ O robieniu przezroczy, H, marzec 1917, $\mathrm{nr}$ 1, s. 21.

${ }^{45}$ A. Ajdukiewicz, Kilka uwag o fotografii, S, 1913, nr 10-11, s. 151-154.

${ }^{46}$ I. Z., Założenie instalacji dzwonkowej w domu, NT, 1934, nr 19, s. 222.

${ }^{47}$ Cykl artykułów Z. M., Podstawy radiotechniki dla poczq̨tkujacych, NT, 1928, nr 2, s. 15; nr 3, s. 18; nr 4, s. 17; nr 5, s. 20-21; nr 9-10, s. 23; Z. Kwiatkowski, Z dziedziny radiotelegrafii, S, 1925, nr 2, s. 23.

${ }^{48}$ S. R., Rozwój historyczny radia, H, 1927, nr 3-4, s. 46; nr 9, s. 78; nr 10, s. 86.

${ }^{49}$ St. W. Bukowski, Zasady zjawisk radiowych, H, 1926, nr 12-13, s. 153-155. 
i wygodny schemat, w razie niejasności autor proponował zaś kontakt listow$n y^{50}$. Niezmiernie ciekawy tekst Uwięzione pioruny! opisuje doświadczenie demonstrujące pioruny wytworzone za pomocą prądu elektrycznego o dużym napięciu. Do przeprowadzenia doświadczenia został wykorzystany cylinder porcelanowy o wysokości $50 \mathrm{~cm}$, do którego doprowadzone zostały przewody od maszyn elektrycznych. Przy coraz to zwiększanym napięciu prąd, którego

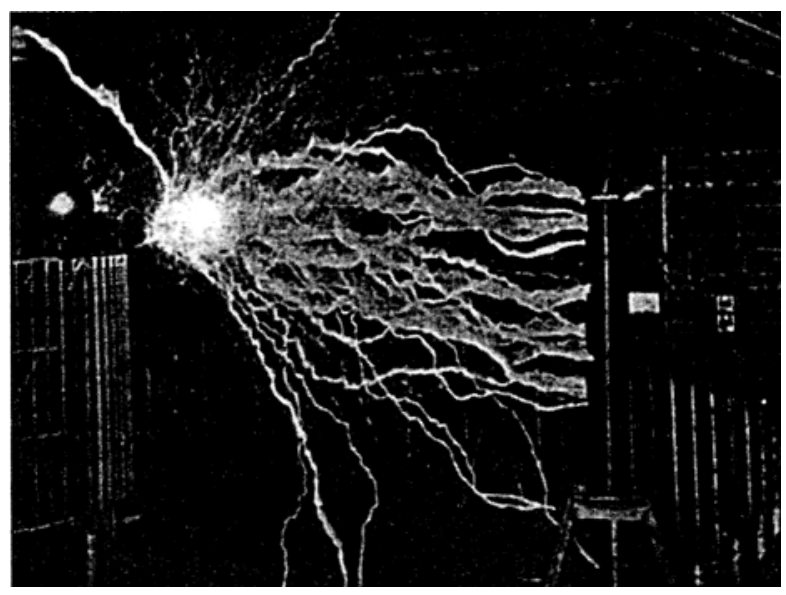

Ryc. 10. Wyładowania w laboratorium Tesli na Long-Island (E. Libański, Uwięzione pioruny!, „Skaut” 1913, nr 21, s. 327)

porcelana nie przewodzi, ,czołga się niejako po powierzchni złego przewodnika" na kształt piorunów. Im większe napięcie, tym piorunów jest więcej, tym są one jaśniejsze ${ }^{51}$.

Mniej liczne były artykuły związane ze sportem. Dotyczą one różnych dyscyplin sportowych, sprzętu sportowego, zawierają wskazówki do ćwiczeń gimnastycznych ${ }^{52}$. Sporty, które pojawiają się na łamach omawianych czasopism, to żeglarstwo ${ }^{53}$, narciarstwo ${ }^{54}$, kolarstwo, ping-pong. Ten ostatni opisany został w Pod urokiem celuloidowej piłeczki. Okazuje się, że popularna gra zwana ping-pongiem była przedmiotem dyskusji - czy można nazwać ją sportem czy tylko miłą grą towarzyską? Tekst opisuje zasady gry i potrzebny sprzęt. Podane zostały prawidłowe wymiary stołu: dł. $275 \mathrm{~cm}$, szer. $152 \mathrm{~cm}$,

${ }^{50}$ L. M., Radio i jego zastosowanie, H, 1925, nr 8, s. 21.

${ }^{51}$ E. Libański, Uwięzione pioruny!, S, 1913, nr 21, s. 325-328.

${ }^{52}$ M. Pigwa, Codzienna gimnastyka harcerza, NT, 1938, nr 9, s. 116-117; tenże, Nie takie znów proste fikanie koziołków, NT, 1938, nr 13, s. 186-187.

${ }^{53}$ Cykl artykułów Z. Grabowski, Kurs żeglarski, H, 1927, nr 9, s. 9; nr 11, s. 93; nr 12, s. 101; nr 13, s. 109; nr 14, s. 117; W. Bublewski (oprac.), Kurs żeglarski, H, 1927, nr 17, s. 131; nr 18, s. 149; nr 19, s. 157; nr 20, s. 165; nr 21, s. 173; nr 22, s. 181; nr 24, s. 215.

${ }_{54}$ Gimnastyka narciarza. Postawa. Główne zasady, H, 1929, nr 7-8, s. 110-111. 
wys. $80 \mathrm{~cm}$. Są one bardzo ważne, gdyż wymiary stołu wpływają na przebieg gry - wybijanie piłeczki na aut, ustawienie graczy ${ }^{55}$.

Wspomnieć należy jeszcze o artykułach związanych z wiedzą o Polsce, w tym szczególnie o cyklu artykułów „Co każdy z nas o Polsce wiedzieć powinien”. Cykl ten dotyczy szeregu problemów, m. in. rodzaju gleb występujących w Polsce ${ }^{56}$, lasów ${ }^{57}$, złóż surowców naturalnych, a więc gazu ziemnego, ropy naftowej ${ }^{58}$, soli i węgla kamiennego ${ }^{59}$, polskiego krajobrazu ${ }^{60}$, dróg lądowych $^{61}$ i komunikacji wodnej ${ }^{62}$, a także Polaków przebywających za granica $^{63}$. W „Harcerzu” w schematycznej formie przedstawiona została gęstość zaludnienia $\mathrm{w}$ Polsce $\mathrm{w}$ stosunku do innych narodów europejskich. $\mathrm{Z}$ przedstawionych danych wynika, że 11 państw miało gęstsze zaludnienie niż Polska ${ }^{64}$.

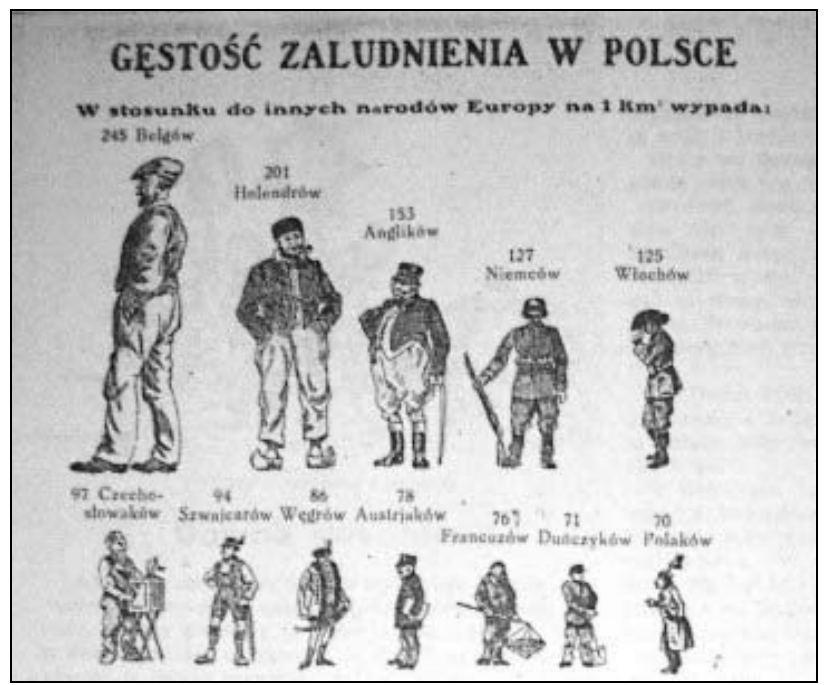

Ryc. 11. Gęstość zaludnienia w Polsce w stosunku do innych narodów Europy na $1 \mathrm{~km}^{2}$ (W. B., Gęstość zaludnienia w Polsce, „Harcerz” 1927, nr 14, s. 119)

${ }^{55}$ J. Żdżarski, Pod urokiem celuloidowej pileczki, NT, 1937, nr 18, s. 266-267.

${ }^{56}$ Co każdy z nas o Polsce wiedzieć powinien. [Gleba urodzajna], S, 1929, nr 2, s. 23.

${ }^{57}$ Co każdy z nas o Polsce wiedzieć powinien. [Las polski], S, 1929, nr 3, s. 38-39.

${ }^{58}$ Co każdy z nas o Polsce wiedzieć powinien. [Gaz ziemny $i$ ropa naftowa], S, 1929, nr 4, s. 55.

${ }^{59}$ Co każdy z nas o Polsce wiedzieć powinien. [Sól i węgiel kamienny], S, 1929, nr 5, s. 70.

${ }^{60}$ Co każdy z nas o Polsce wiedzieć powinien. [Krajobraz], S, 1929, nr 6, s. 91-92.

${ }^{61}$ Co każdy z nas o Polsce wiedzieć powinien. [Drogi ladowe], S, 1929, nr 8, s. 151.

${ }^{62}$ Co każdy z nas o Polsce wiedzieć powinien. [Komunikacja wodna], S, 1929, nr 9, s. 168.

${ }^{63}$ Co każdy z nas o Polsce wiedzieć powinien. [Polacy za granica], S, 1929, $\mathrm{nr} 7$, s. $135-136$.

${ }^{64}$ W. B., Gestość zaludnienia w Polsce, H, 1927, nr 14, s. 119. 
Pojawiały się też artykuły dotyczące tradycji narodowych, godła, barw, odznaczeń, jak np. Orderu Polonia Restistuta, który został ustanowiony 4 lutego $1921 \mathrm{r}$. w celu nagradzania zasług dla państwa i społeczeństwa. Oznakami orderu są krzyż orderowy czteroramienny i srebrna gwiazda orderowa ośmioramienna oraz wstęga orderowa z pasowej mory jedwabnej z białymi prążkami ${ }^{65}$.

Odnotowane zostały zmiany w zasadach ortografii, jednak krótki tekst zatytułowany Wprowadzamy nowa pisownie jest jednym z nielicznych związanych z językiem polskim. Wówczas wprowadzone zostały zasady rozdzielnej pisowni wyrażeń składających się $\mathrm{z}$ dwóch lub więcej wyrazów, np. za darmo, na wskroś. Ustalono zasadę pisania przez ,"” wyrazów takich, jak np. Dania, harmonia, akademia. Ustalono też pisownię , wielu słów, które do tej pory pisano w sposób różny. Na przykład pisać należy: brąz, pąsy, kolęda, umiem i rozumiem, muskuł i smalec, musztra i szkontrum, koślawy i sierść. Dowolnie pisać można skarpa i szkarpa, urwis i urwisz. Pisze się dalej: ekierka i krokiet, algebra, legenda, gencjana, geneza, ale Giewont, giermek, higiena. Pisze się dwóch i osiem. Ustalona również została pisownia słowa druhna (przez h) ${ }^{66}$.

Pojawiały się także teksty poświęcone pierwszej pomocy i obronności. Jako przykład posłużyć może artykuł Pomoc w nagłych wypadkach. Pierwszą rzeczą, którą należy zrobić w każdym wypadku, jest natychmiastowe wezwanie lekarza.

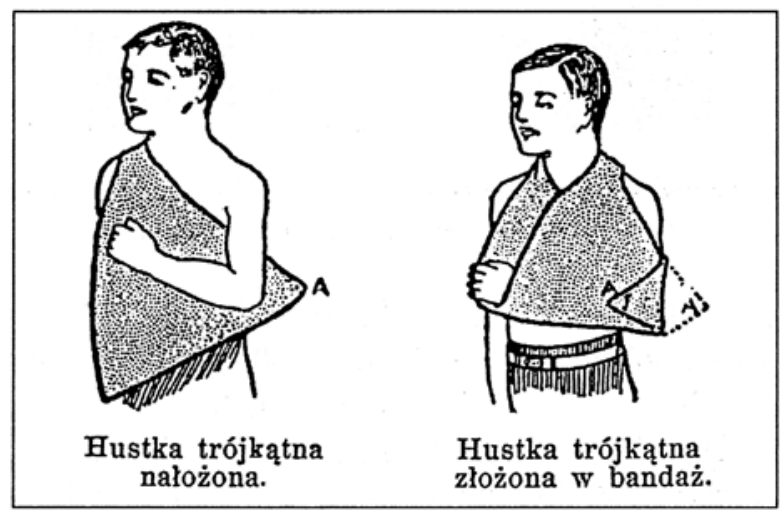

Ryc. 12. Opatrunek z chusty trójkątnej (Pomoc w naglych wypadkach, „Skaut” 1912, nr 13, s. 8)

Artykuł opisuje sposoby tamowania krwotoków z żyły, tętnicy oraz krwotoków wewnętrznych oraz ilustruje jak rozpoznać złamanie kości i jak je opatrzyćc7. Artykuł o karabinie „Mannlicher” opisuje bardzo szczegółowo jego budowę i parametry techniczne. Podano także informacje dotyczące rodzajów stosowanej

\footnotetext{
${ }^{65}$ Order Polonia Restituta, H, 1928, nr 9, s. 74.

${ }^{66}$ Wprowadzamy nowa pisownie, NT, 1936, nr 13, s. 151.

${ }^{67}$ Pomoc w nagtych wypadkach, S, 1912, nr 13, s. 6-8.
} 
amunicji oraz podstawowe zasady konserwacji broni. Został wzbogacony o szczegółowe rysunki karabinu w dużym formacie, jako dodatek do numeru ${ }^{68}$.

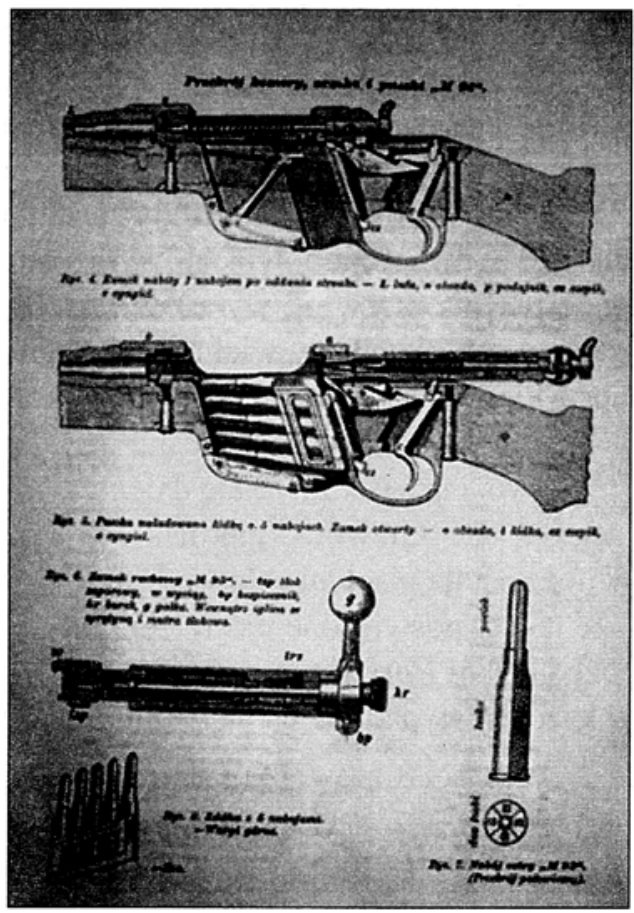

Ryc. 13. Przekrój komory, zamka i puszki karabinu „Manlicher” (X. Vocavelli, Karabin „Mannlicher”, dodatek do „Skauta” 1913, nr 4)

Pisma docierały do większości młodzieży harcerskiej. W przypadku czasopism o zasięgu ogólnopolskim stanowiło to ok. 90 tys. osób ${ }^{69}$. Był to edukacyjny wymiar działalności harcerstwa. Dobór treści kształtował postawy patriotyczne stąd wiele informacji dotyczących Polski, jej historii, przyrody i geografii. Umiejętności poruszania się i orientacji $\mathrm{w}$ terenie były przydatne obywatelowi, mogły się przydać w przypadku, gdy będzie bronić Ojczyzny. Edukacja w harcerstwie stanowiła zatem doskonałe uzupełnienie szkolnego systemu kształcenia.

${ }^{68}$ X. Vocavelli, Karabin „Mannlicher”, S, 1913, nr 1-3, s. 44-47; dodatek do „Skauta” 1913, nr 4; S, 1913, nr 1-3, s. 59-62.

${ }^{69}$ W. Błażejewski, Z dziejów harcerstwa polskiego (1910-1939), Warszawa 1985, s. $338-339$. 